\title{
Widespread and major losses in multiple ecosystem services as a result of agricultural expansion in the Argentine Chaco
}

\author{
María Paula Barral $^{1,2}$ (D) | Sebastian Villarino ${ }^{2,3}$ (D) $\mid$ Christian Levers $^{4}$ | \\ Matthias Baumann $^{4}$ | Tobias Kuemmerle ${ }^{4,5}$ | Matias Mastrangelo ${ }^{2,3}$
}

${ }^{1}$ INTA, Centro Regional Buenos Aires Sur, Estación Experimental Agropecuaria Balcarce, Balcarce, Argentina

${ }^{2}$ Grupo de Estudio de Agroecosistemas y Paisajes Rurales, Facultad de Ciencias Agrarias, Universidad Nacional de Mar del Plata, Balcarce, Argentina

${ }^{3}$ Consejo Nacional de Investigaciones Científicas y Técnicas (CONICET), Mar del Plata, Argentina

${ }^{4}$ Geography Department, HumboldtUniversität zu Berlin, Berlin, Germany

${ }^{5}$ Integrative Research Institute on Transformations of Human-Environment Systems (IRI THESys), Humboldt-University Berlin, Berlin, Germany

\section{Correspondence}

María Paula Barral

Email: barral.mariapaula@inta.gob.ar

Funding information

German Research Foundation, Grant/

Award Number: KU 2458/5-1; Argentinean Ministry of Environment and the National Agency of Science, Grant/Award Number: PICTO 2014-0046; German Federal Ministry of Education and Research, Grant/ Award Number: PASANOA 031B0034A; Belgian Science Policy Office Research Programme for Earth Observation, Grant/ Award Number: REFORCHA SR/00/338

Handling Editor: Guadalupe Peralta

\section{Abstract}

1. Where agriculture expands into tropical and subtropical forests, social-ecological impacts are typically strong. However, where and how frontier development impacts on ecosystem functioning and services is often unclear, including which services trade-off against agricultural production. This constitutes a major barrier towards planning for more sustainable outcomes in deforestation frontiers.

2. Here we assessed spatiotemporal change in multiple ecosystem services in the Argentine Chaco, a global deforestation hotspot. We modelled and mapped five ecosystem functions (i.e. carbon storage in biomass, carbon storage in soil, erosion control, excess rainfall retention by vegetation and soil fertility) which together provide three ecosystem services (i.e. agricultural suitability, climate regulation and flood regulation) for 1985, 2000 and 2013. We then employed this information to identify and map: (a) main trade-offs between ecosystem services and agricultural production, and (b) bundles of changes in ecosystem services through the use of Self-Organizing Maps.

3. Our results highlight that land-use changes since 1985 have led to widespread and drastic declines in ecosystem functions and services across the Argentine Chaco. Mean losses of ecosystem services ranged between $6 \%$ and $10 \%$ for flood regulation, climate regulation and agricultural suitability. The largest losses occurred in the Dry Chaco subregion between 2000 and 2013.

4. We find two main types of trade-offs between regulating ecosystem services and agricultural production. Increases in crop and pasture production occurred along with large and moderate losses, respectively, in flood regulation and climate regulation over $20 \%$ of the region.

5. Our mapping of bundles identified five common patterns of change in ecosystem services, delineating areas of stable or degrading ecosystem service supply. This provides a powerful template for adaptive spatial planning.

6. Synthesis and applications. Using the Argentinean Chaco as an example, we demonstrate how combining fine-scale land-use maps with biophysical models provides deep insights into the spatiotemporal patterns of changes in ecosystem services, and their trade-offs with agricultural production. The periodic updating of maps of trade-offs and bundles of change in ecosystem services provides key inputs for 
the adaptive management of highly dynamic and threatened landscapes, such as those in tropical and subtropical deforestation frontiers.

\section{KEYWORDS}

commodity frontiers, deforestation, ecosystem service modelling, environmental impacts, multifunctionality, spatial trade-offs

\section{1 | INTRODUCTION}

Agricultural expansion can increase the provisioning of food, fibre and biomass, but also entails stark environmental impacts (Garrett et al., 2018; Tilman, Balzer, Hill, \& Befort, 2011). These impacts, however, are increasingly distributed unevenly across the globe, with the most rapid and extensive agricultural frontiers found in tropical and subtropical regions (Hansen et al., 2013; Laurance, Sayer, \& Cassman, 2014). These regions contain some of the last remaining land reserves (Lambin et al., 2013), but are also rich in unique biodiversity and store vast amounts of carbon, both of which typically suffer as agriculture expands (Parr, Lehmann, Bond, Hoffmann, \& Andersen, 2014; Pendrill et al., 2019). Understanding how agricultural frontiers advance in the tropics, and which environmental impacts co-occur with them, is therefore important.

Advancing agricultural frontiers are the result of land manag ers' individual decisions aimed at increasing the production of food animal feed, fibre or fuel (Mastrangelo, Gavin, Laterra, Linklater, \& Milfont, 2014). This alters key ecosystem functions, in turn creating or amplifying trade-offs among ecosystem services (Mastrangelo \& Laterra, 2015). For example, the expansion of monocultures to produce agricultural commodities (e.g. soybean, oil palm) into tropical and subtropical forests reduces the multifunctionality of these ecosystems (Mastrangelo, Weyland, et al., 2014) and their supply of services related to climate regulation (Quintas-Soriano, Castro, Castro, \& García-Llorente, 2016), flood regulation (Rogger et al., 2017), pollination (Potts et al., 2016) or water regulation (Villarino, Studdert, \& Laterra, 2019). Importantly, there are critical feedbacks among these changes, as agricultural production itself depends on regulating services (Bennett \& Balvanera, 2007; Bommarco, Vico, \& Hallin, 2018). Mitigating trade-offs, avoiding unwanted outcomes and more generally steering agricultural frontiers towards sustainable futures, thus depends on tracing the links between land-use change, ecosystem functions and ecosystem service supply.

Despite considerable advances in mapping agricultural expansion on the one hand (e.g. Baumann, Gasparri, et al., 2017; Graesser, Aide, Grau, \& Ramankutty, 2015; Song et al., 2018), and ecosystem functioning and services on the other (Laterra, Barral, Carmona, \& Nahuelhual, 2016; Raudsepp-Hearne, Peterson, \& Bennett, 2010; Schulp, Van Teeffelen, Tucker, \& Verburg, 2016), spatially explicit, fine-resolution assessments of the relationships among both remain rare (Stürck et al., 2016). This is particularly so for tropical and subtropical forest regions, which harbour the world's most dynamic agricultural frontiers (Garrett et al., 2018).
The few existing assessments in such regions typically rely on coarse proxies of ecosystem services (Carrasco, Webb, Symes, Koh, \& Sodhi, 2017; Leh, Matlock, Cummings, \& Nalley, 2013; Locatelli, Imbach, \& Wunder, 2014; Rukundo et al., 2018), which are often opaque to the ecosystem functions underlying specific ecosystem services. This, in turn, has led to calls for more biophysical realism in ecosystem service assessments through modelling surfaces of regionalized primary data (Eigenbrod et al., 2010; Lavorel et al., 2017; Seppelt, Dormann, Eppink, Lautenbach, \& Schmidt, 2011). Linking such efforts to land-use change maps would allow us to reveal how land-use change impacts ecosystem functions, and how these impacts translate into change in ecosystem services (Boerema, Esler, Meire, Rebelo, \& Bodi, 2016). Unfortunately, such assessments are rare (Rieb et al., 2017) and typically local, thus not covering the most relevant, broader scales for policymaking and spatial planning.

Promising avenues for assessing links between land use, ecosystem functions and services across broader scales are the concepts of bundles and archetypical change. Ecosystem functions or services often change in similar ways in response to a certain type and magnitude of land-use change (Grace, Vestergaard, Bøcher, Dalgaard, \& Svenning, 2014). Thus, sets of bundles of ecosystem functions or services that covary across time and space can be identified and mapped (Queiroz et al., 2015; Raudsepp-Hearne et al., 2010; Renard, Rhemtulla, \& Bennett, 2015). This provides a powerful means to understand spatial variation in trade-offs in data-scarce regions (Baró, Gómez-Baggethun, \& Haase, 2017; Berry, Turkelboom, Verheyden, \& Martín-López, 2015). Likewise, these bundles can be traced in time, providing insight into how trade-offs and synergies evolve as land-use change progresses (Renard et al., 2015). However, we know of only two studies that have done so, one for Europe (Mouchet et al., 2017) and one for Canada (Raudsepp-Hearne et al., 2010), where landscapes have been comparatively stable. No such assessment has, to the best of our knowledge, been carried out in any agricultural frontier in the tropics or subtropics, where trade-offs can be expected to be very stark.

South America's dry forest and savannas are currently experiencing the highest rates of agricultural expansion globally (Garrett et al., 2018) including in the Cerrado, the Chiquitania and the Chaco ecosystems (Baumann, Israel, et al., 2017; Piquer-Rodríguez, Baumann, et al., 2018). The Chaco in particular has recently emerged as a global deforestation hotspot, with about $21 \%$ (15.8 million ha) of its woodlands transformed between 1980 and 2012 (Vallejos et al., 2015). How these transformations have impacted bundles of 
ecosystem functions and services, however, remains unknown. This is problematic because, as in many tropical and subtropical deforestation frontiers, such information is urgently needed to inform regional land-use planning (Aguiar et al., 2018).

Chaco ecosystems support many benefits, such as buffering from climatic extremes, reducing flood risk and maintaining land agricultural productivity. Yet all of these benefits can be compromised as agricultural production expands into natural ecosystems. Land-use planners and policymakers seeking to lessen such tradeoffs urgently require better knowledge of how and where land-use changes impact the delivery of these benefits. Here we map three ecosystem services and five ecosystem functions that underpin these services using the ECOSER protocol (ECOSER, 2020). This protocol has recently been designed and implemented in South America (Barral, Laterra, \& Maceira, 2019; Laterra et al., 2016; Portalanza et al., 2019), and allows for (a) modelling ecosystem functions based on ecosystem properties (e.g. land-cover, soil, climate, topography) and (b) quantifying and mapping ecosystem services based on the multiple ecosystem functions that underpin them. We then used Self Organizing Maps to identify typical bundles of ecosystem services and their changes. Specifically, we address the following research questions:

1. How did ecosystem functions and services change across the Argentine Chaco between 1985 and 2013?
2. What are the main trade-offs between agricultural production and ecosystem services in the region, and where are these located?

3. What are typical bundles of changes in ecosystem services across the region, and how are these spatially distributed?

\section{MATERIALS AND METHODS}

\section{1 | Study area}

The Argentine Chaco encompasses 60\% (around 700,000 $\mathrm{km}^{2}$ ) of the South American Chaco, a tropical and subtropical region covered by a mosaic of dry and humid forests, savannas, grasslands, shrublands and croplands (Figure 1). Annual precipitation ranges from 1,200 mm in the Wet Chaco to $450 \mathrm{~mm}$ in the Dry Chaco, concentrated from November to April followed by a long dry season from May to September (Bucher, 1982). Mean annual temperature is $22^{\circ} \mathrm{C}$, with high temperature in spring and summer determining evapotranspiration exceeding precipitation (Bianchi \& Cravero, 2010). Most abundant soil types are Mollisols and Entisols, with loam-silty and loam textures (Villarino et al., 2017). The Argentine Chaco contains three subregions. In the east, and the Wet Chaco is a large plain covered by savannas interspersed with marshes and forests on riverbanks and higher lands. The Dry Chaco expands from the Andean foothills to the
FIGURE 1 Location of the Chaco ecoregion in South America (a), climatic subregions of the Chaco (b), and land cover in 1985 (c), 2000 (d) and 2013 (e; based on Baumann, Gasparri, et al., 2017)
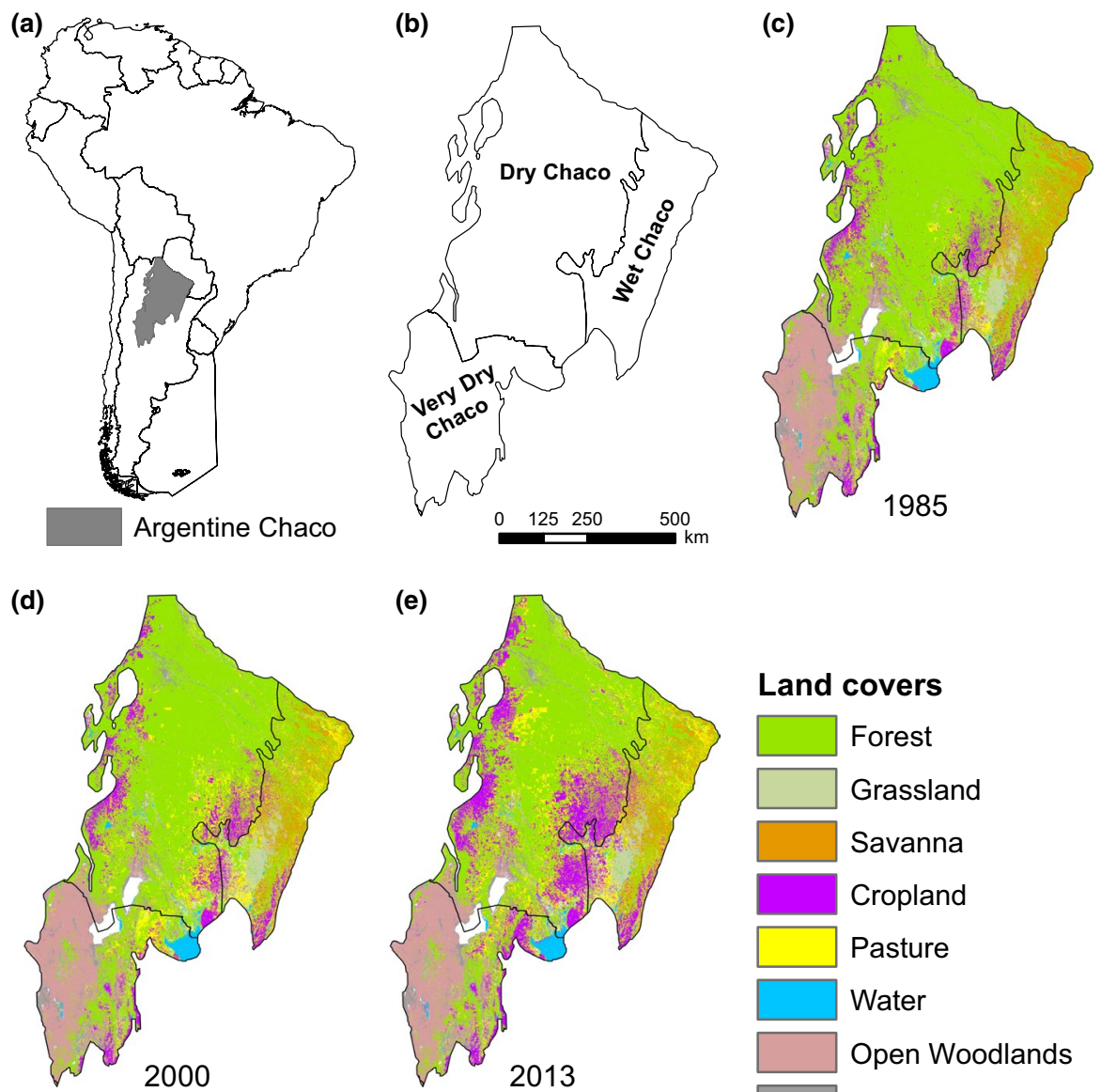

\section{Land covers}

Forest

Grassland

Savanna

Cropland

Pasture

Water

Open Woodlands

Bare 
Wet Chaco, covered by xerophilous forests dominated by quebrachos (Schinopsis balansae, Schinopsis lorentzii and Aspidosperma quebracho) and algarrobos (Prosopis spp.). In the south, the Very Dry Chaco has less rainfall and a hillier terrain, and natural vegetation is dominated by shrubs (Morello, Mateucci, Rodríguez, \& Silva, 2012). Deforestation in this region started in the 1970s and accelerated in the 1990s, stimulated by new technologies (i.e. GM soybeans) and favourable policies (le Polain de Waroux et al., 2018). Deforestation rates surged particularly in the 2000s, with input intensive and large-scale monoculture soybean systems and pasture expansion pushing agricultural frontiers deep into the forest towards the semi-arid core of the Chaco.

\subsection{Assessment of ecosystem functions and services}

To quantify and map ecosystem services supply, we applied the ECOSER protocol (ECOSER, 2020; Laterra et al., 2016). This protocol builds on the conceptual framework of the ecosystem service cascade (Haines-Young \& Potschin, 2010), in which the biophysical structure of ecosystems supports ecosystem functions (Fisher, Turner, \& Morling, 2009), which in turn supply ecosystem services that are of direct benefit to society. Several conceptual frameworks and classification schemes exist in ecosystem services research (Braat \& Groot, 2012), each of them with their own strengths and weaknesses. All of them can be useful for organizing ecosystem service assessments, as long as they are flexible enough to be adjusted to specific research objectives and the social-ecological characteristics of study cases.

Most procedures for quantifying and mapping ecosystem services do not require regionalized data, and many rely on proxy indicators or generalized 'ecological production functions', which can produce a considerable mismatch between maps and reality (Eigenbrod et al., 2010). More popular or well-known ecosystem service assessment protocols (i.e. InVest, ARIES) are based on the Millennium Ecosystem Assessment framework, and thus do not make a clear distinction between ecosystem functions and services. Unlike these, ECOSER quantifies and maps ecosystem functions and services separately, using primary data from within the region. This allows better capturing of the spatial heterogeneity of ecosystem functions that together produce the supply of ecosystem services. In ECOSER, the relative contribution of ecosystem functions to particular services varies depending on the ecological and regional context (Weyland, Barral, \& Laterra, 2017; Figure 2). This clear distinction between ecosystem functions and services is useful as each ecosystem function can contribute to multiple ecosystem services, and each ecosystem service can be the result of multiple functions. ECOSER is provided online (ECOSER, 2020) and the modelling tools can be integrated into ArcGIS or QGIS.

We assessed three ecosystem services that are particularly important for the Argentine Chaco (Cáceres, Tapella, Quétier, \& Díaz, 2015; Mastrangelo, 2018) and the five ecosystem functions that underpin them (Figure 2). We read the cascade from right to left (from benefits to structures) to select ecosystem functions and services, as ecosystem services are the targets of planning actions and the boundary object that facilitates the science-policy dialogue (Potschin-Young et al., 2018; Spangenberg, von Haaren, $\&$ Settele, 2014). For example, reducing flooded areas (benefit) requires flood regulation (ES2, Figure 2), an ecosystem service supported by multiple ecosystem functions, among them the retention of excess rainfall (EF1) and the retention of soil sediments (EF3) by vegetation. At the same time, the capacity to control soil erosion

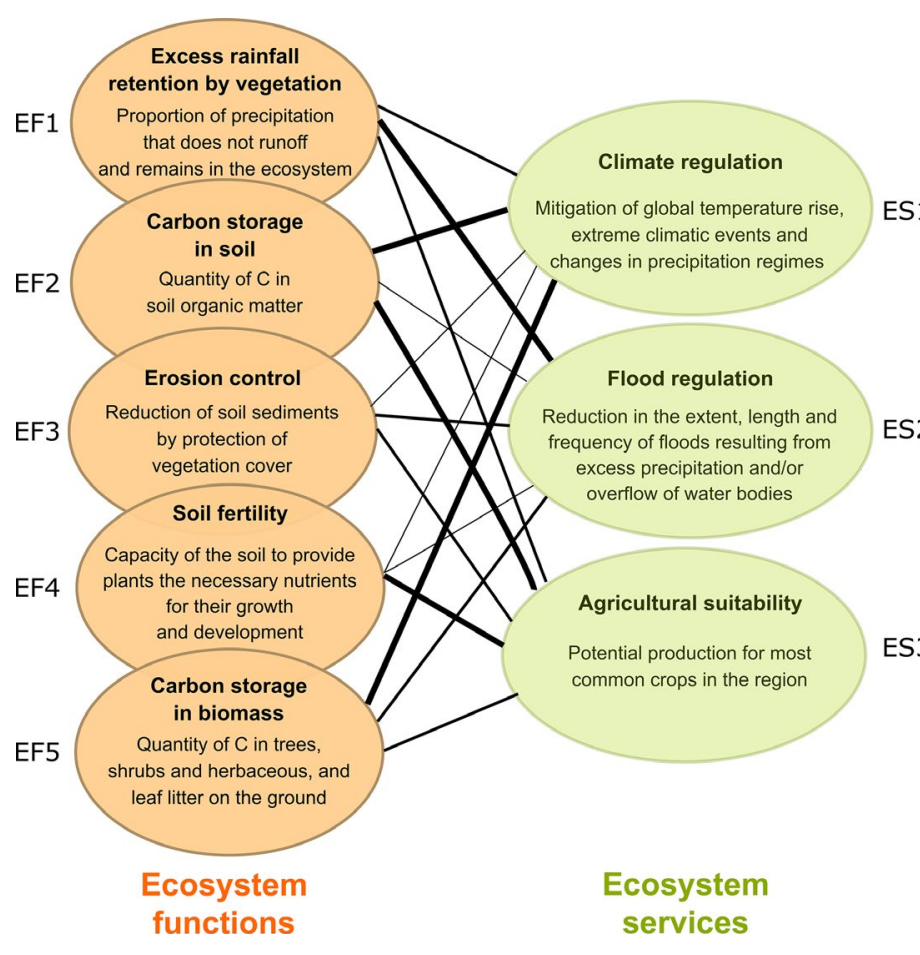

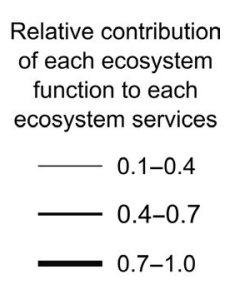

ES3
FIGURE 2 Linkages between the ecosystem functions (EF) and services (ES) assessed for the Argentine Chaco. Line thickness is proportional to the relative contribution of ecosystem functions to specific services (obtained from Weyland et al., 2017) 
(EF3) and the storage of carbon in soils (EF2) contribute to maintain the suitability of land for agricultural use (ES3). Land-use changes, such as the conversion of forests to cropland, modify and often reduce these ecosystem functions (Villarino et al., 2017), creating trade-offs between agricultural production and ecosystem services such as climate regulation (ES1).

We first quantified and mapped the five ecosystem functions across the study region for the years 1985, 2000 and 2013 at a resolution of $30 \mathrm{~m}$, using models based on soil properties, topography, land cover and other biophysical variables (see Table 1; for detail on input data and preprocessing see Supporting Information). Since ecosystem function maps had different measurement units, we normalized them to range between 0 and 100 (min-max normalization). We then generated ecosystem service maps according to:

$$
\mathrm{ESS}_{i}=\sum_{i=1}^{n} b_{i j} \times \mathrm{EF}_{j}
$$

where the supply of ecosystem service $i\left(E_{S}\right)$ is obtained from the linear combination of $j$ ecosystem functions $\left(E_{j}\right)$, weighted by the relative contribution of each $j$ function to that service $\left(b_{i j}\right)$. The relative contributions of ecosystem functions to ecosystem services were based on an expert-knowledge elicitation study (Figure 2; Table S5; Weyland et al., 2017).

\section{3 | Regional change and trade-off analyses}

To assess regional changes in ecosystem functions and services between 1985 and 2013 (research question 1, Figure 3), we calculated the relative differences in each function (except for soil fertility, which depended only on soil properties that were assumed to be constant over our time period, see Supporting Information) and service for three time periods (2000-1985, 2013-2000 and 20131985) and averaged the relative differences at the regional and subregional levels.

To evaluate trade-offs between ecosystem services and agricultural production in the region (research question 2, Figure 3), we classified gridcells according to (a) the magnitude of ecosystem service losses and (b) the type of land-use conversion as an indicator of the magnitude of changes in agricultural production. For (a), we classified gridcells according to the magnitude of losses from 1985 to 2013 in each ecosystem service into: small losses, moderate losses and large losses, defined as the lower, middle and upper third of the distribution of values. For (b), we classified gridcells according to the land use change from 1985 to 2013 into three categories (no conversion, conversion to crop, conversion to pasture). To assess relationships between ecosystem service losses and land-use conversions, we ran a correspondence analysis (Queen, Quinn, \& Keough, 2002). Finally, we mapped areas where land-use conversions led to large losses of ecosystem services (i.e. trade-off areas) according to the correspondence analysis.

\section{4 | Mapping bundles of ecosystem services}

We used Self-Organizing Maps to map typical bundles of change in ecosystem services across the region (research question 3 , Figure 3). Self-Organizing Maps are an automated clustering technique using an unsupervised competitive learning algorithm

TAB LE 1 Models used for quantifying and mapping each ecosystem function assessed (for a detailed description of the procedures see Supporting Information)

\begin{tabular}{|c|c|c|}
\hline Ecosystem function & Model description & Main references \\
\hline $\begin{array}{l}\text { Excess rainfall retention by } \\
\text { vegetation }\end{array}$ & $\begin{array}{l}\text { The model employs the Curve Number methods to calculate } \\
\text { the run-off as the result of the interaction between } \\
\text { vegetation and soil type. Then, the amount of floodwater } \\
\text { retained by vegetation is calculated by subtracting } \\
\text { run-off from precipitation }\end{array}$ & $\begin{array}{l}\text { Barral et al. (2019); Fu, Wang, Xu, and } \\
\text { Yan (2013); NRCS (1986) }\end{array}$ \\
\hline Carbon stored in soil & $\begin{array}{l}\text { The amount of carbon stored in soil organic matter is } \\
\text { calculated considering the initial soil organic carbon stock } \\
\text { (under reference condition, pristine or semi-pristine } \\
\text { condition) and stock change factor (according to the } \\
\text { vegetation cover) }\end{array}$ & IPCC (2006); Villarino et al. (2018) \\
\hline Carbon stored in biomass & $\begin{array}{l}\text { Values of carbon storage in biomass (carbon in trees, shrubs, } \\
\text { herbaceous vegetation and leaf litter on the ground) for each } \\
\text { vegetation cover }\end{array}$ & $\begin{array}{l}\text { Baumann, Gasparri, et al. (2017); } \\
\text { IPCC (2006) }\end{array}$ \\
\hline Erosion control & $\begin{array}{l}\text { The model employs the Revised Universal Soil Loss Equation } \\
\text { (RUSLE) to calculate sediment loss rates for two conditions: } \\
\text { bare soil and different types of vegetation covers. Then, } \\
\text { these values are subtracted }\end{array}$ & $\begin{array}{l}\text { Renard, Foster, Weesies, and } \\
\text { Porter } 1991\end{array}$ \\
\hline Soil fertility & $\begin{array}{l}\text { This index establishes a numerical value of the production } \\
\text { capacity of soils (assuming that the productive capacity of } \\
\text { the soil depends on its intrinsic properties) }\end{array}$ & INTA (1990); Riquier et al. (1970) \\
\hline
\end{tabular}




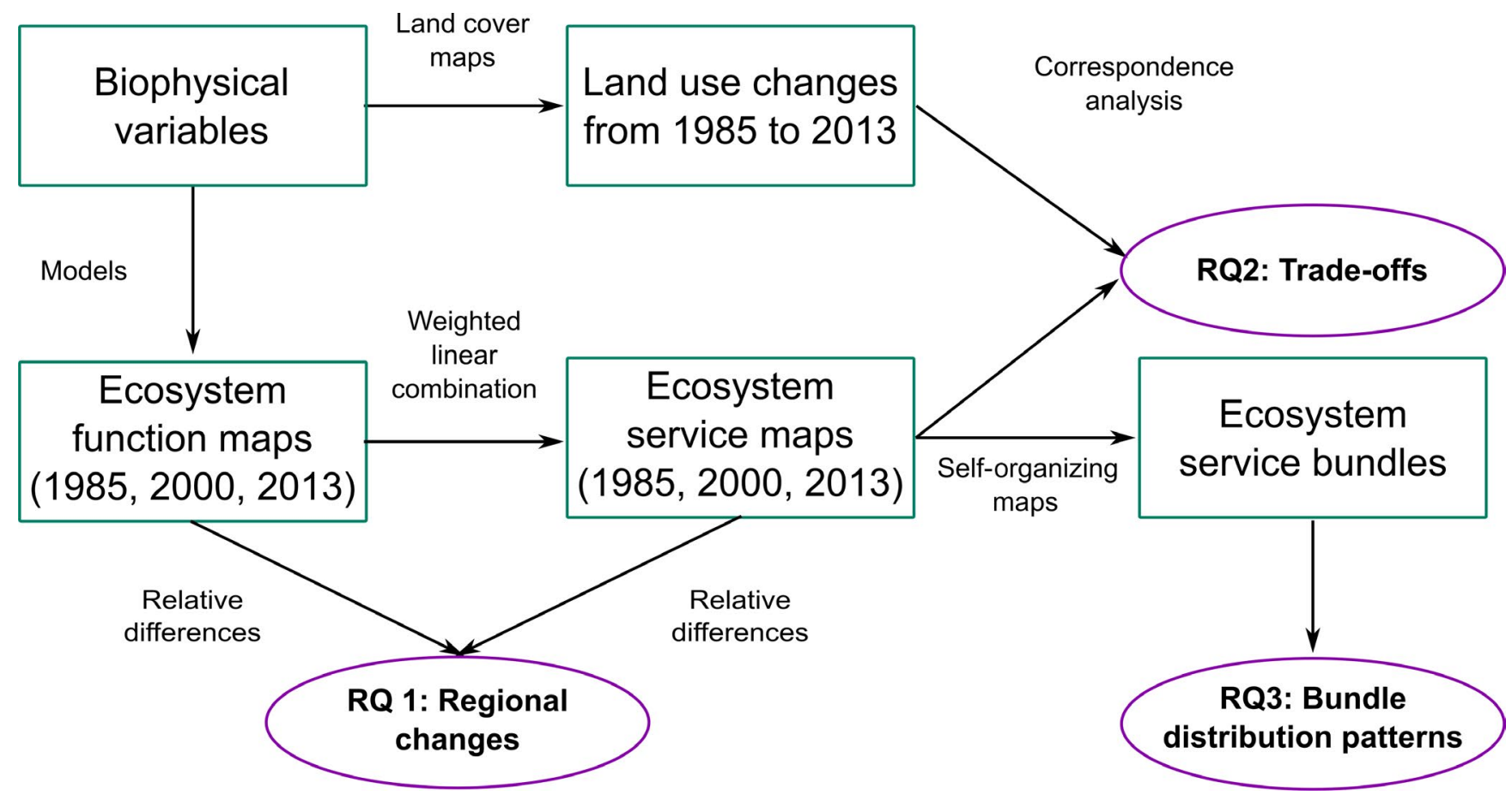

FIGURE 3 Overall workflow to map five ecosystem functions and three ecosystem services, which then served as inputs to identify trade-offs and map bundles of ecosystem services over time

(Kohonen, 2001). They are well-suited to analyse and visualize high-dimensional data, reduce data complexity by grouping observations based on their similarity in feature space, and preserve the topology of the input data (Ripley, 1996), rendering them a useful tool to investigate major patterns in human-environment systems (Levers et al., 2018; Václavík, Lautenbach, Kuemmerle, \& Seppelt, 2013).

To reduce computational load we aggregated the ecosystem services layers from their native $30-\mathrm{m}$ resolution to a $1-\mathrm{km}$ resolution, by calculating averages per gridcell. We calculated the absolute difference between 1985 and 2013. All input layers used in our cluster analyses were scaled to zero mean and unit standard deviation ( $z$ scores) to make cluster results comparable (i.e. how strongly the level of ecosystem service change at a given location deviates from the regional average change). As our results are relative to the respective average change across the region, mean and standard deviation values for each indicator were reported to allow for a meaningful interpretation of our cluster results (Table S6; Supporting Information).

Self-Organizing Maps require a priori definition of the number of clusters. To identify the appropriate number of clusters, we performed a sensitivity analysis with different cluster numbers ranging from 1 to 25 . We determined the final number of clusters by searching for the natural break point in the mean Euclidean distance of the samples to their cluster centroid (Maulik \& Bandyopadhyay, 2002) and by the Davies-Bouldin cluster validity index (Davies \& Bouldin, 1979), which relates intra- to inter-cluster variability (see Figure S1 in the Supporting Information). These metrics are commonly used to identify the optimal cluster number (Chaimontree, Atkinson, \& Coenen, 2010).
We ran the cluster analysis with ecosystem service data for 1985 plus absolute differences between 1985 and 2013 (six input layers, five clusters). Including the 1985 baseline situation is important for the correct interpretation of observed changes. We used the KOHONEN (Wehrens \& Buydens, 2007) and CLUSTERSIM (Walesiak $\&$ Dudek, 2014) packages in R to perform all analyses. Once clusters were defined, we mapped cluster memberships for all gridcells. We named these bundles after the observed trend in ecosystem services change (stable or degrading). For bundles with a stable trend, we named them after the baseline level in 1985 (low, moderate or high). For bundles with a degrading trend, we named them after the magnitude of degradation between 1985 and 2013 (moderate or high).

\section{3 | RESULTS}

\subsection{Changes in ecosystem functions and services between 1985 and 2013}

All ecosystem functions and services we assessed declined from 1985 to 2013 in the Argentine Chaco (Figure 4). At regional level, the functions that experienced the largest average losses were carbon storage in biomass and excess rainfall retention (overall loss of $15 \%$ and $6 \%$, respectively, Figure $4 a$ ), with local losses of up to $95 \%$ and $50 \%$ respectively. In terms of ecosystem services, mean losses were $8 \%$ for climate regulation, $7 \%$ for flood regulation and $6 \%$ for agricultural suitability (Figure $4 \mathrm{~b}$ ).

Ecosystem functions declined more strongly after 2000 (Figure 4a), with average losses doubling for carbon storage in 
(a)

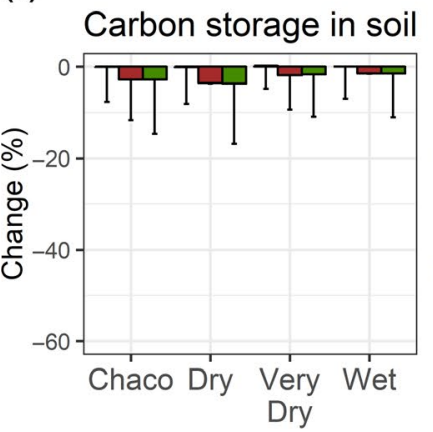

Excess rainfall retention by vegetation

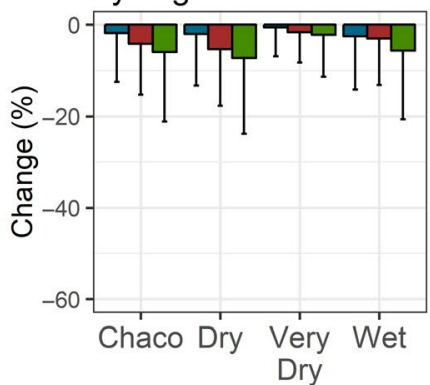

Carbon storage in biomass

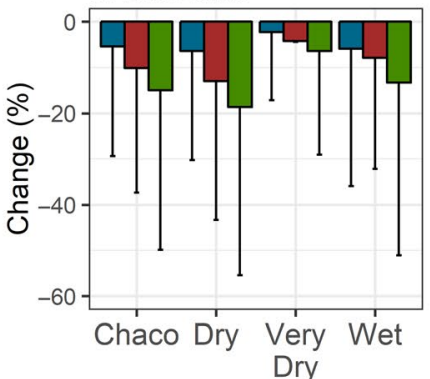

Erosion control

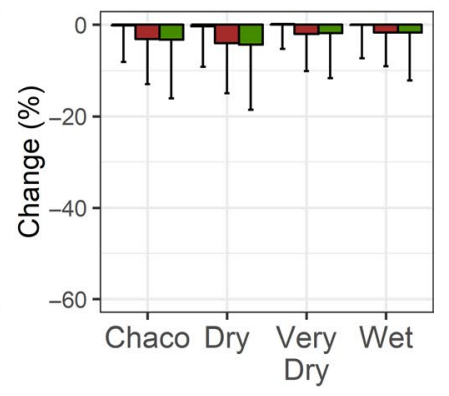

(b) Climate regulation

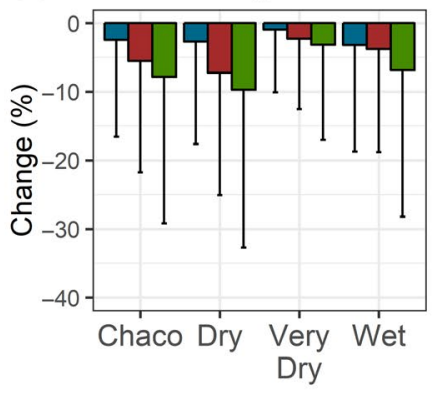

1985-2000
Flood regulation

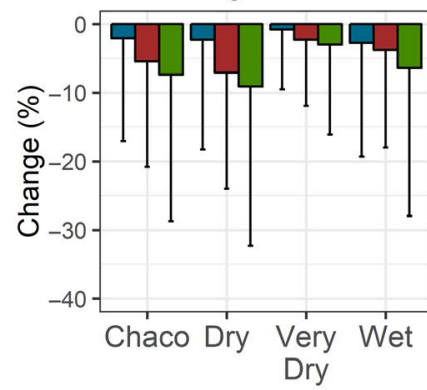

$\square$ 2000-2013

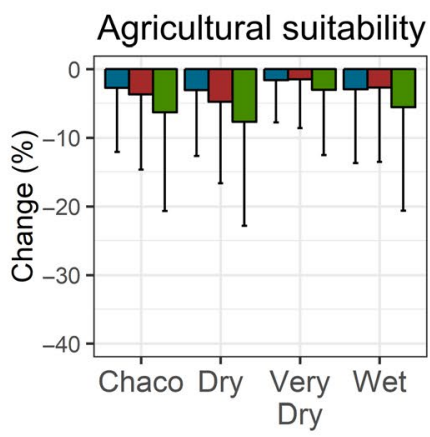

1985-2013

FIGURE 4 Relative changes in ecosystem functions (a) and services (b) in 1985-2000 and 2000-2013 for the entire Chaco and the three subregions. Blue represents changes between 1985 and 2000, red represents changes between 2000 and 2013 and green represents changes between 1985 and 2013. Error bars depict SD

biomass (5\%-10\%) and excess rainfall retention (2\%-4\%) and tripling for carbon storage in soil and erosion control (1\%-3\%) compared to pre-2000 levels. A similar acceleration occurred for ecosystem services, with climate regulation decreasing by $2 \%$ and $6 \%$ and flood regulation by $2 \%$ and $5 \%$ for $1985-2000$ and $2000-2013$, respectively (Figure 4b). Declines varied among subregions, with highest average losses in the Dry Chaco subregion. Carbon storage in biomass experienced the highest average losses in this subregion as well (19\%), followed by excess rainfall retention (7\%). Thirteen per cent of this subregion experienced losses above $60 \%$ in carbon storage in biomass while for excess rainfall retention, $11 \%$ of this subregion suffered losses of $25 \%-50 \%$. We observed a similar trend for the three ecosystem services, for which average losses ranged between $8 \%$ and $10 \%$.

\section{2 | Trade-offs between agricultural production and ecosystem services}

The magnitude of losses in ecosystem services depended on the type of land-use changes occurring from 1985 to 2013. Large losses in flood regulation and climate regulation were positively associated with conversion to cropland, while moderate losses in these ecosystem services were positively associated with conversion to pasture (Figure 5b). Therefore, regulating ecosystem services had stronger trade-offs with crop rather than with pasture production.
Areas with these major types of trade-offs between agricultural production and ecosystem services were spatially segregated across the study region, due to the environmental gradient and the heterogeneity in agricultural frontier expansion. Areas with strong tradeoffs between crop production and regulating ecosystem services (green areas, $9 \%$ of the region, Figure $5 a$ ) were mainly located in the sub-humid fringes of the Dry Chaco subregion, coinciding with older agricultural frontier expansion. Areas with moderate trade-offs between pasture production and regulating ecosystem services (orange areas, $11 \%$ of the region, Figure 5 a) were mainly located in the driest parts of the Chaco, where there has been more recent agricultural frontier expansion. In sum, the expansion of crop and pasture production has compromised key regulating ecosystem services in over $20 \%$ of the region and $27 \%$ of the Dry Chaco subregion.

\subsection{Bundles of change in ecosystem services}

Combining baseline (1985) maps of ecosystem service levels with maps of changes in these services ( $\triangle E S$ between 1985 and 2013) resulted in five bundles (Figure 6).

$\triangle E S$ bundle 1-'Stable low ecosystem service supply' (17\% of the area): areas of pre-1985 conversions. Here 1985 levels of all three ecosystem services were lower than 1985 regional averages, while 1985-2013 changes were lower than 1985-2013 regional average changes, resulting in minor losses (between $0.03 \%$ and $1.73 \%$ ). 
(a)

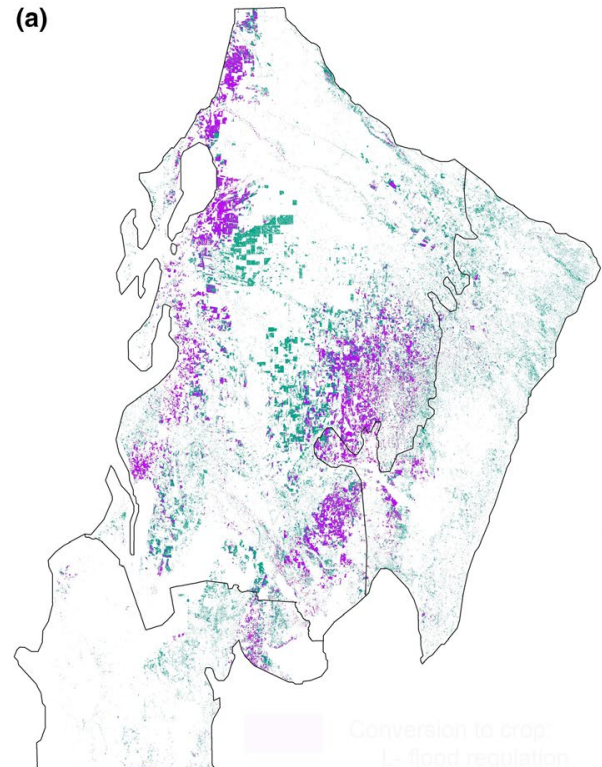

(b)

CA factor map

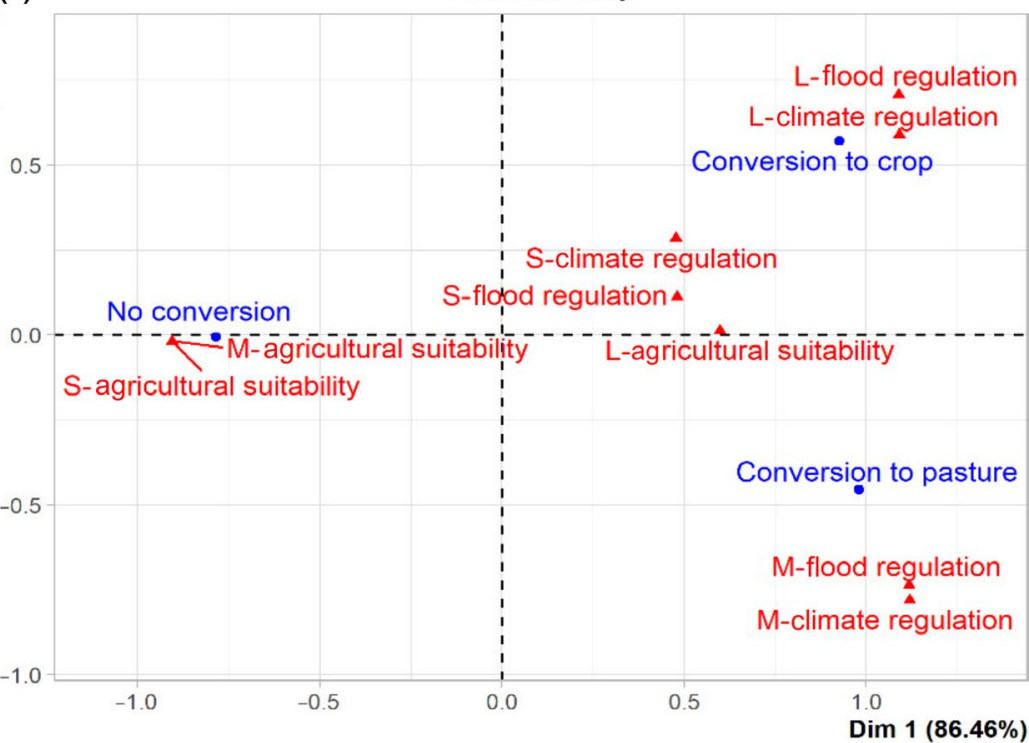

Conversion to pasture:

$\mathrm{M}$-flood regulation

M-climate regulation

FIGURE 5 Trade-offs between agricultural production and regulating ecosystem services in the Chaco region. Map of trade-off areas (a), showing the areas where land-use conversions led to large losses of ecosystem services, according to the correspondence analysis (b). In (a), trade-off areas between crop production and flood and climate regulation are show in violet, and trade-off areas between pasture production and flood and climate regulation are shown in green. In (b), types of land-use conversions are represented by blue circles, and magnitudes of ecosystem services losses by red triangles $(\mathrm{S}=$ small losses, $\mathrm{M}=$ moderate losses, $\mathrm{L}=$ large losses)
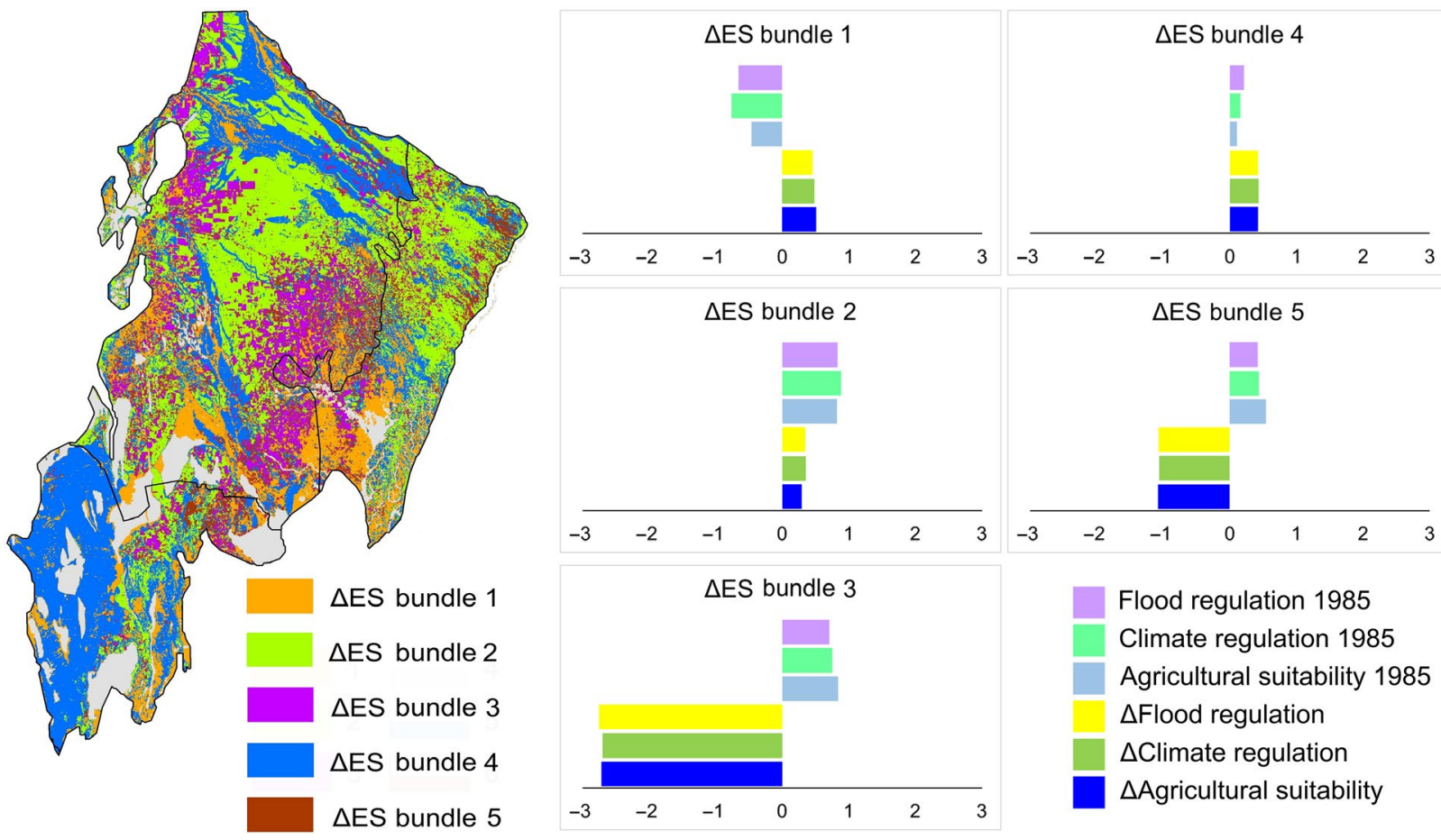

Flood regulation 1985

Climate regulation 1985

Agricultural suitability 1985

$\Delta$ Flood regulation

$\triangle$ Climate regulation

$\Delta$ Agricultural suitability

FIGURE 6 Spatial distribution of ecosystem service bundles based on 1985 baselines and changes between 1985 and 2013 across the Chaco. Bar plots show Z-scores of ecosystem service levels (e.g. Flood regulation 1985) and ecosystem service changes (e.g. $\Delta$ Flood regulation). For ecosystem service 1985-levels, positive Z-scores indicate levels larger than the regional average level, while negative $Z$-scores indicate levels smaller than the regional average level. As all ecosystem services declined from 1985 to 2013 , positive Z-scores indicate losses smaller than the regional average loss, while negative Z-scores indicate losses larger than the regional average loss 
$\triangle E S$ bundle 2-'Stable high ecosystem service supply' (29\% of the area): areas of stable remnant dry and humid natural vegetation cover. Here 1985 levels of all three ecosystem services were higher than 1985 regional averages. Changes between 1985 and 2013 were lower than regional averages (less than one standard deviation). This corresponded, as in $\triangle E S$ bundle 1 , to minor losses in all ecosystem services.

$\triangle E S$ bundle 3-'High degradation of ecosystem services' (9\% of the area): areas of recent conversion of natural vegetation into cropland and pastures. Here 1985 levels of all three ecosystem services were higher than 1985 regional averages, as in $\triangle E S$ bundle 2, but 1985-2013 changes were almost three standard deviations lower than 1985-2013 regional average changes. All ecosystem services decreased by $28 \%-44 \%$ between 1985 and 2013.

$\triangle E S$ bundle 4-'Stable moderate ecosystem service supply' (32\% of the area): agriculturally marginal areas, such as areas of excessive dryness or wetness. Here 1985 levels of all three ecosystem services were close to 1985 regional averages. Changes in all ecosystem services in 1985-2013 were slightly lower than regional averages, with minor losses of $0.4 \%$ (agricultural suitability), $1.5 \%$ (flood regulation) and $1.8 \%$ (climate regulation).

$\triangle E S$ bundle 5-'Moderate degradation of ecosystem services' (13\% of the area): areas of high fragmentation of natural vegetation. Here 1985 levels of all three ecosystem services were higher than average levels, similar to $\triangle E S$ bundles 2 and 3. Declines between 1985 and 2013 in all three ecosystem services were higher than regional average changes (i.e. 15\% for agricultural suitability, 22\% for flood regulation and $24 \%$ for climate regulation).

\section{4 | DISCUSSION}

Expanding agriculture contributes to raising global agricultural production, yet typically goes along with major environmental impacts (Power, 2010). Nowhere are these trade-offs stronger than in the world's tropical and subtropical dry forests and savannas, which are rich in biodiversity and carbon (Semper-Pascual et al., 2018; Solbrig, 1996), yet where agriculture has expanded drastically in recent decades (Laurance et al., 2014). This typically occurs against a background of sparse protected area networks, weakly developed conservation policies and limited knowledge of how trade-offs are distributed in space. A major research challenge in such situations, characterized by data scarcity and dynamically changing landscapes, is how to generate knowledge useful for planners and policymakers seeking to mitigate tradeoffs between agriculture and the environment (Rau, von Wehrden, \& Abson, 2018).

Focusing on the Argentine Chaco, a global deforestation and biodiversity hotspot, we combine high-resolution land-cover maps with biophysical models to assess changes in ecosystem services from 1985 to 2013, a period of marked agricultural expansion. Our analyses lead to three key insights. First, all ecosystem functions and services we assessed showed major and widespread declines during the 28 years studied, with substantial variation among periods and subregions. Second, $20 \%$ of the region showed moderate and strong trade-offs between agricultural production and key regulating services over the study period. Third, five areas showed similar patterns of ecosystem service change in response to land-use dynamics, configuring bundles that provide a powerful template for land-use planning. Based on these insights, we provide explicit suggestions for adaptive management and policymaking in active agricultural frontiers.

We find major and widespread losses in all ecosystem functions and services, across the Chaco region and for both time periods we assessed. The largest average losses, observed in the Dry Chaco in between 2000 and 2013, coincided with the area and timing of highest deforestation rates in the region (Vallejos et al., 2015). Notably, active agricultural frontiers covering $30 \%$ of the Dry Chaco experienced losses above $60 \%$ in carbon storage in biomass. This is in line with Volante, Alcaraz-Segura, Mosciaro, Viglizzo, and Paruelo (2012) and Paruelo et al., (2016) who found lower and more seasonal carbon gains in areas with more drastic conversion of native vegetation to agriculture. Our results, in addition to covering a much longer time frame at resolutions an order of magnitude higher, go beyond these findings by demonstrating that those areas also experienced the largest declines in rainfall retention and erosion control, thereby reducing flood and climate regulation and land suitability for agriculture. This adds to the mounting evidence that the current agricultural expansion model undermines the long-term sustainability of the region, as evidenced by rising of saline water tables (Amdan, Aragón, Jobbágy, Volante, \& Paruelo, 2013; Giménez, Mercau, Nosetto, Páez, \& Jobbágy, 2016), increasing wind speed and dust storms (Sacchi, Powell, Gasparri, \& Grau, 2017), increasing severity and frequency of floods (Murgida, González, \& Tiessen, 2014) and decreasing soil functionality (Villarino et al., 2019). Taken together, this underlines the high vulnerability of the region to continued agricultural expansion and deforestation.

We find two main types of trade-offs between agricultural production and ecosystem services. On the sub-humid fringes of the Dry Chaco, where agriculture expanded earlier, increases in crop production at the expense of native forests occurred along with-and probably brought about-the largest losses in flood and climate regulation in the region during the study period. In turn, these key regulating services showed comparatively lower losses in response to increases in pasture area for cattle production towards the drier core of the region, where agriculture expanded more recently. This spatiotemporal pattern of crop and pasture expansion is similar in neighbouring commodity frontiers, such as in the Amazon (e.g. DeFries, Foley, \& Asner, 2004; O'Connell et al., 2018) and the Cerrado (Kennedy et al., 2016; Strassburg et al., 2017). Knowing whether trade-offs in areas of pasture expansion can be lessened by land-use planning, or are just part of a transition towards stronger trade-offs, requires periodic updating of multi-year analyses on the links between landuse and ecosystem service change, because trade-offs are dynamic in space and time (Macchi et al., 2020). In addition, monitoring of 
trade-offs is critical to identify potential negative feedbacks between actual agricultural production and agricultural suitability (Rieb et al., 2017).

We find five bundles of changes in ecosystem services across the region, each of them associated with particular land-use dynamics over the study period. Ecosystem service supply was more stable (bundles 2 and 4) where native vegetation cover was maintained until 2013, mainly due to strong environmental constraints for agricultural expansion. In contrast, moderate to high levels of ecosystem service degradation (bundles 3 and 5) occurred where aridity and wetness are not too strong and agricultural suitability was high in 1985. Bundles of changes in ecosystem services represent an advancement over static bundles based on snapshot assessments, as they allow the identification of ecosystem service trajectories or 'syndromes', and are a starting point for capturing temporal change in ecosystem services (e.g. Jaligot, Chenal, \& Bosch, 2019; Rau et al., 2018; Renard et al., 2015). Furthermore, dynamic bundles can be used to target land-use planning actions, tailored to the changing relationships between land-use and ecosystem service change.

As for all model and data-driven approaches, there are some limitations. First, bundle identification is sensitive to the selection of ecosystem functions and services, as well as the input data used to map them (Bagstad, Cohen, Ancona, McNulty, \& Sun, 2018). Adding more functions and services would be advantageous and would likely further increase the value of our bundles for spatial planning. Second, models to map ecosystem services are notoriously difficult to validate and calibrate with primary data representative of the study area, especially across large regions (Palomo et al., 2018), such as in our case. Third, more explicit consideration of the role of landscape configuration in driving ecosystem service supply would increase the biophysical realism of our approach (Chaplin-Kramer et al., 2015).

Our analyses provide a number of concrete suggestions for land-use planning in the Argentine Chaco. The fate of social-ecological systems in this region is not determined by local demands because the food produced regionally could feed 30 times its population (Mastrangelo \& Aguiar, 2019), and the vast majority of this produce is exported. Given this, it can be questioned whether accepting the drastic trade-offs in terms of ecosystem services we uncovered here is justified, a situation similar to other South American agricultural frontiers (e.g. Chaplin-Kramer et al., 2015). Halting deforestation would drastically reduce trade-offs and make major contributions to lowering carbon emissions (Baumann, Gasparri, et al., 2017), while not necessarily limiting income opportunities for agribusinesses (Piquer-Rodríguez, Butsic, et al., 2018). If expansion into remaining natural vegetation is unavoidable, mitigating the impacts of land-use change on ecosystem services through improved land-use planning and more environmentally friendly production systems is key.

Our findings support three concrete and connected suggestions for policymaking and spatial planning. First, bundles of stable ecosystem service supply ( 2 and 4 ) should be the focus of conservation efforts, for example, by increasing their conservation status in upcoming revisions of the provincial zoning plans mandated by the Argentinean Forest Law (Aguiar et al., 2018). Second, conservation of ecosystem services at the forest-agriculture interface (i.e. the interface between bundle 2 and bundles 3 and 5) will require targeted actions to lessen trade-offs, given the increasing fragmentation of native vegetation and potential spillover of environmental impacts from agriculture- to forest-dominated landscapes. This can be achieved through integrating elements of native vegetation into cattle production systems, such as retaining a significant part of the canopy in silvopastures, using diverse grass species or maintaining forest strips, all of which can retain some of the ecosystem functions otherwise lost (Barral, Rey Benayas, Meli, \& Maceira, 2015). Third, bundles of declining or already low ecosystem service supply (1, 3 and 5 ) should be the target of actions to restore ecosystem functions such as carbon storage in biomass (Basualdo, Huykman, Volante, Paruelo, \& Piñeiro, 2019), which yield positive cascading effects on flood and climate regulation and agricultural suitability.

Solutions to avoid and mitigate trade-offs between agricultural expansion and the environment remains one of the most pressing research issues for sustainability science (Mastrangelo, Sun, Seghezzo, \& Muller, 2019). Using the Argentinean Chaco, a global deforestation hotspot (Hansen et al., 2013), as an example, we demonstrate how combining fine-scale land-use maps with biophysical models can provide deep insights into the spatiotemporal patterns of changes in ecosystem functions and services, and the trade-offs with agricultural production. The periodic updating of maps of trade-offs and bundles of change in ecosystem services provides key inputs for the adaptive management of highly dynamic and threatened landscapes, such as those in tropical and subtropical agricultural frontier regions.

\section{ACKNOWLEDGEMENTS}

This work was supported by the German Federal Ministry of Education and Research (BMBF, project PASANOA 031B0034A), the Argentinean Ministry of Environment and the National Agency of Science (PICTO 2014-0046), the German Research Foundation (DFG, project KU 2458/5-1) and by the Belgian Science Policy Office Research Programme for Earth Observation (belspo-STEREO-III, project REFORCHA, SR/00/338). We are deeply grateful to two anonymous reviewers and editors Dr. Martín Nuñez and Dr Guadalupe Peralta for very helpful and constructive comments on an earlier manuscript version.

\section{AUTHORS' CONTRIBUTIONS}

M.P.B. led the modelling and mapping work and C.L., S.V. and M.P.B. contributed the analyses; M.M., T.K. and M.P.B. wrote the manuscript. All authors contributed to conceiving the ideas, contributed critically to the drafts and gave final approval for publication.

\section{DATA AVAILABILITY STATEMENT}

Data are available via the Dryad Digital Repository https://doi. org/10.5061/dryad.18931zcv3 (Barral et al., 2020). 


\section{ORCID}

María Paula Barral iD https://orcid.org/0000-0001-7834-491X Sebastian Villarino (iD https://orcid.org/0000-0003-1850-447X

\section{REFERENCES}

Aguiar, S., Mastrangelo, M., Collazo, M., Camba Sans, G., Mosso, C., Ciuffoli, L., ... Veron, S. (2018). ¿Cuál es la situación de la Ley de Bosques en la Región Chaqueña a diez años de su sanción? Revisar su pasado para discutir su futuro. Ecologia Austral, 28, 400-417. https:// doi.org/10.25260/EA.18.28.2.0.677

Amdan, M., Aragón, R., Jobbágy, E., Volante, J. N., \& Paruelo, J. M. (2013). Onset of deep drainage and salt mobilization following forest clearing and cultivation in the Chaco plains (Argentina). Water Resources Research, 49(10), 6601-6612. https://doi.org/10.1002/wrcr.20516

Bagstad, K. J., Cohen, E., Ancona, Z. H., McNulty, S. G., \& Sun, G. (2018). The sensitivity of ecosystem service models to choices of input data and spatial resolution. Applied Geography, 93, 25-36. https://doi. org/10.1016/j.apgeog.2018.02.005

Baró, F., Gómez-Baggethun, E., \& Haase, D. (2017). Ecosystem service bundles along the urban-rural gradient: Insights for landscape planning and management. Ecosystem Services, 24(April), 147-159. https://doi.org/10.1016/j.ecoser.2017.02.021

Barral, M. P., Laterra, P., \& Maceira, N. (2019). Flood mitigation ecosystem service in landscapes of Argentina's Pampas: identifying winning and losing farmers. Journal of Environmental Management, 240(October 2018), 168-176. https://doi.org/10.1016/j.jenvman.2019.03.099

Barral, M. P., Villarino, S., Levers, C., Baumman, M., Kuemmerle, T., \& Mastrangelo, M. (2020). Data from: Widespread and major losses in multiple ecosystem services as a result of agricultural expansion in the Argentine Chaco. Dryad Digital Repository, https://doi.org/ 10.5061/dryad.18931zcv3

Barral, P., Rey Benayas, J., Meli, P., \& Maceira, N. (2015). Quantifying the impacts of ecological restoration on biodiversity and ecosystem services in agroecosystems: A global meta-analysis. Agriculture, Ecosystems and Environment, 202, 223-231. https://doi.org/10.1016/ j.agee.2015.01.009

Basualdo, M., Huykman, N., Volante, J. N., Paruelo, J. M., \& Piñeiro, G. (2019). Lost forever? Ecosystem functional changes occurring after agricultural abandonment and forest recovery in the semiarid Chaco forests. Science of the Total Environment, 650, 1537-1546. https://doi. org/10.1016/j.scitotenv.2018.09.001

Baumann, M., Gasparri, I., Piquer-Rodriguez, M., Gavier Pizarro, G., Griffiths, P., Hostert, P., \& Kuemmerle, T. (2017). Carbon emissions from agricultural expansion and intensification in the Chaco. Global Change Biology, 23(5), 1902-1916. https://doi.org/10.1111/ gcb.13521

Baumann, M., Israel, C., Piquer-Rodríguez, M., Gavier-Pizarro, G., Volante, J., \& Kuemmerle, T. (2017). Deforestation and cattle expansion in the Paraguayan Chaco 1987-2012. Regional Environmental Change, 17(4), 1179-1191. https://doi.org/10.1007/s10113-017-1109-5

Bennett, E. M., \& Balvanera, P. (2007). The future of production systems in a globalized world. Frontiers in Ecology and the Environment, 5(4), 191-198. https://doi.org/10.1890/1540-9295(2007)5[191:TFOPSI] 2.0.CO;2

Berry, P., Turkelboom, F., Verheyden, W., \& Martín-López, B. (2015). Ecosystem service bundles. OpenNESS, 10, 1-5.

Bianchi, R., \& Cravero, S. (2010). Atlas climático Digital de la República Argentina. Buenos Aires: Ediciones.

Boerema, A., Esler, K. J., Meire, P., Rebelo, A. J., \& Bodi, M. B. (2016). Are ecosystem services adequately quantified? Journal of Applied Ecology, 54(2), 358-370. https://doi.org/10.1111/1365-2664.12696

Bommarco, R., Vico, G., \& Hallin, S. (2018). Exploiting ecosystem services in agriculture for increased food security. Global Food Security, 17, 57-63. https://doi.org/10.1016/j.gfs.2018.04.001
Braat, L. C., \& Groot, R. D. (2012). The ecosystem services agenda: Bridging the worlds of natural science and economics, conservation and development, and public and private policy. Ecosystem Services, 1(1), 4-15.

Bucher, E. (1982). Chaco and Caatinga - South American arid savannas, woodlands and thickets. In B. Huntley \& B. Walker (Eds.), Cology of Tropical Savannas (pp. 48-79). Berlin, Germany: Springer-Verlag.

Cáceres, D. M., Tapella, E., Quétier, F., \& Díaz, S. (2015). The social value of biodiversity and ecosystem services from the perspectives of different social actors. Ecology and Society, 20(1). https://doi. org/10.5751/ES-07297-200162

Carrasco, L. R., Webb, E. L., Symes, W. S., Koh, L. P., \& Sodhi, N. S. (2017). Global economic trade-offs between wild nature and tropical agriculture. PLoS Biology, 15(7). https://doi.org/10.1371/journal. pbio. 2001657

Chaimontree, S., Atkinson, K., \& Coenen, F. (2010). Best clustering configuration metrics: Towards multiagent based clustering. In L. Cao, Y. Feng, \& J. Zhong (Eds.), Advanced data mining and applications. Lecture Notes in Computer Science (Vol. 6440, pp. 48-59). Berlin, Heidelberg, Germany: Springer.

Chaplin-Kramer, R., Sharp, R. P., Mandle, L., Sim, S., Johnson, J., Butnar, I., ... Kareiva, P. M. (2015). Spatial patterns of agricultural expansion determine impacts on biodiversity and carbon storage. Proceedings of the National Academy of Sciences of the United States of America, 112(24), 7402-7407. https://doi.org/10.1073/pnas.1406485112

Davies, D. L., \& Bouldin, D. W. (1979). A cluster separation measure. IEEE Transactions on Pattern Analysis and Machine Intelligence, 1(2), 224227. https://doi.org/10.1109/TPAMI.1979.4766909

DeFries, R. S., Foley, J. A., \& Asner, G. P. (2004). Land-use choices: Balancing human needs and ecosystem function. Frontiers in Ecology and the Environment, 2(5), 249-257. https://doi.org/10.1890/15409295(2004)002[0249:LCBHNA]2.0.CO;2

ECOSER. (2020). ECOSER. Collaborative evaluation and mapping of ecosystem services supply and socio-ecological vulnerability for land-use planning. Retrieved from www.eco-ser.com.ar

Eigenbrod, F., Armsworth, P. R., Anderson, B. J., Heinemeyer, A., Gillings, S., Roy, D. B., ... Gaston, K. J. (2010). The impact of proxybased methods on mapping the distribution of ecosystem services. Journal of Applied Ecology, 47(2), 377-385. https://doi.org/10.1111/ j.1365-2664.2010.01777.x

Fisher, B., Turner, K., \& Morling, P. (2009). Defining and classifying ecosystem services for decision making. Ecological Economics, 68(3), 643-653. https://doi.org/10.1016/j.ecolecon.2008.09.014

Fu, B., Wang, Y. K., Xu, P., \& Yan, K. (2013). Mapping the flood mitigation services of ecosystems - A case study in the Upper Yangtze River Basin. Ecological Engineering, 52, 238-246. https://doi.org/10.1016/j. ecoleng.2012.11.008

Garrett, R. D., Koh, I., Lambin, E. F., le Polain de Waroux, Y., Kastens, J. H., \& Brown, J. C. (2018). Intensification in agriculture-forest frontiers: Land use responses to development and conservation policies in Brazil. Global Environmental Change, 53, 233-243. https://doi. org/10.1016/j.gloenvcha.2018.09.011

Giménez, R., Mercau, J., Nosetto, M., Páez, R., \& Jobbágy, E. (2016). The ecohydrological imprint of deforestation in the semiarid Chaco: Insights from the last forest remnants of a highly cultivated landscape. https:// doi.org/10.1002/hyp.10901

Grace, K., Vestergaard, M., Bøcher, P. K., Dalgaard, T., \& Svenning, J. (2014). Landscape and urban planning bundling ecosystem services in Denmark: Trade-offs and synergies in a cultural landscape. Landscape and Urban Planning, 125, 89-104. https://doi.org/10.1016/j.landu rbplan.2014.02.007

Graesser, J., Aide, T., Grau, H., \& Ramankutty, N. (2015). Cropland/ pastureland dynamics and the slowdown of deforestation in Latin America. Environmental Research Letters, 10(3). https://doi.org/ 10.1088/1748-9326/10/3/034017 
Haines-Young, R., \& Potschin, M. (2010). Proposal for a Common International Classification of Ecosystem Goods and Services (CICES) for integrated environmental and economic accounting (pp. 1-23). Nottingham, UK: European Environment Agency.

Hansen, M. C., Potapov, P. V., Moore, R., Hancher, M., Turubanova, S. A. A., Tyukavina, A., ... Kommareddy, A. (2013). High-resolution global maps of 21st-century forest cover change. Science, 342(6160), 850-853.

INTA. (1990). Atlas de Suelos de la República Argentina, Escala 1:500.000, CIRN. Buenos Aires, Argentina: Instituto de Evaluación de Tierras.

IPCC. (2006). Agriculture, forestry and other land use. In 2006 IPCC Guidelines for National Greenhouse Gas Inventories (Vol. 4). Hayama, Japan: Institute for Global Environmental Strategies on behalf of the IPCC.

Jaligot, R., Chenal, J., \& Bosch, M. (2019). Assessing spatial temporal patterns of ecosystem services in Switzerland. Landscape Ecology, 1-16. https://doi.org/10.1007/s10980-019-00850-7

Kennedy, C. M., Hawthorne, P. L., Miteva, D. A., Baumgarten, L., Sochi, K., Matsumoto, M., ... Kiesecker, J. (2016). Optimizing land use decision-making to sustain Brazilian agricultural profits, biodiversity and ecosystem services. Biological Conservation, 204, 221-230. https:// doi.org/10.1016/j.biocon.2016.10.039

Kohonen, T. (2001). Self-organizing maps. Springer Series in Information Sciences (Vol. 30, 3rd ed., 502 pp.). Berlin, Heidelberg, Germany: Springer Verlag.

Lambin, E. F., Gibbs, H. K., Ferreira, L., Grau, R., Mayaux, P., Meyfroidt, P., ... Munger, J. (2013). Estimating the world's potentially available cropland using a bottom-up approach. Global Environmental Change, 23(5), 892-901. https://doi.org/10.1016/j.gloenvcha.2013. 05.005

Laterra, P., Barral, P., Carmona, A., \& Nahuelhual, L. (2016). Focusing conservation efforts on ecosystem service supply may increase vulnerability of socio-ecological systems. PLoS One, 11(5), e0155019. https://doi.org/10.1371/journal.pone.0155019

Laurance, W., Sayer, J., \& Cassman, K. (2014). Agricultural expansion and its impacts on tropical nature. Trends in Ecology \& Evolution, 29(2), 107-116. https://doi.org/10.1016/j.tree.2013.12.001

Lavorel, S., Bayer, A., Bondeau, A., Lautenbach, S., Ruiz-Frau, A., Schulp, N., ... Marba, N. (2017). Pathways to bridge the biophysical realism gap in ecosystem services mapping approaches. Ecological Indicators, 74, 241-260. https://doi.org/10.1016/j.ecolind.2016.11.015

le Polain de Waroux, Y., Baumann, M., Gasparri, N. I., Gavier-Pizarro, G., Godar, J., Kuemmerle, T., ... Meyfroidt, P. (2018). Rents, actors, and the expansion of commodity frontiers in the Gran Chaco. Annals of the American Association of Geographers, 108(1), 204-225. https:// doi.org/10.1080/24694452.2017.1360761

Leh, M. D. K., Matlock, M. D., Cummings, E. C., \& Nalley, L. L. (2013). Agriculture, ecosystems and environment quantifying and mapping multiple ecosystem services change in West Africa. Agriculture, Ecosystems and Environment, 165, 6-18. https://doi.org/10.1016/j. agee.2012.12.001

Levers, C., Müller, D., Erb, K., Haberl, H., Jepsen, M. R., Metzger, M. J., ... Kuemmerle, T. (2018). Archetypical patterns and trajectories of land systems in Europe. Regional Environmental Change, 18(715), https:// doi.org/10.1007/s10113-015-0907-x

Locatelli, B., Imbach, P., \& Wunder, S. (2014). Synergies and trade-offs between ecosystem services in Costa Rica. Environmental Conservation, 41(1), 27-36. https://doi.org/10.1017/S0376892913000234

Macchi, L., Decarre, J., Goijman, A. P., Mastrangelo, M., Blendinger, P. G., Gavier-Pizarro, G. I., ... Kuemmerle, T. (2020). Trade-offs between biodiversity and agriculture are moving targets in dynamic landscapes. Journal of Applied Ecology. https://doi.org/10.1111/1365-2664.13699

Mastrangelo, M. (2018). Aproximaciones al estudio del comportamiento de los productores agropecuarios en el Chaco Seco. Ecologia Austral, 28, 418-434. https://doi.org/10.25260/EA.18.28.2.0.644
Mastrangelo, M., \& Aguiar, S. (2019). Are ecological modernization narratives useful for understanding and steering social-ecological change in the Argentine Chaco? Sustainability, 11(13), 3593. https://doi. org/10.3390/su11133593

Mastrangelo, M., Gavin, M., Laterra, P., Linklater, W., \& Milfont, T. (2014). Psycho-social factors influencing forest conservation intentions on the agricultural frontier. Conservation Letters, 7(2), 103-110. https:// doi.org/10.1111/conl.12033

Mastrangelo, M., \& Laterra, P. (2015). From biophysical to social-ecological trade-offs: Integrating biodiversity conservation and agricultural production in the Argentine Dry Chaco. Ecology and Society, 20(1). https://doi.org/10.5751/ES-07186-200120

Mastrangelo, M., Sun, Z., Seghezzo, L., \& Muller, D. (2019). Surveybased modeling of land-use intensity in agricultural frontiers of the Argentine Dry Chaco. Land Use Policy, 88, 104183. https://doi. org/10.1016/j.landusepol.2019.104183

Mastrangelo, M., Weyland, F., Villarino, S., Barral, M. P., Nahuelhual, L., \& Laterra, P. (2014). Concepts and methods for landscape multifunctionality and a unifying framework based on ecosystem services. Landscape Ecology, 29(2), 345-358. https://doi.org/10.1007/s1098 0-013-9959-9

Maulik, U., \& Bandyopadhyay, S. (2002). Performance evaluation of some clustering algorithms and validity indices. IEEE Transactions on Pattern Analysis and Machine Intelligence, 24(12), 1650-1654. https://doi. org/10.1109/TPAMI.2002.1114856

Morello, J., Mateucci, S., Rodríguez, F., \& Silva, M. (2012). Ecorregiones y complejos ecosistémicos argentinos. Buenos Aires: Orientación Gráfica Editora.

Mouchet, M. A., Paracchini, M. L., Schulp, C., Stürck, J., Verkerk, P. J., Verburg, P. H., \& Lavorel, S. (2017). Bundles of ecosystem (dis)services and multifunctionality across European landscapes. Ecological Indicators, 73, 23-28. https://doi.org/10.1016/j.ecolind.2016.09.026

Murgida, A., González, M., \& Tiessen, H. (2014). Rainfall trends, land use change and adaptation in the Chaco salteño region of Argentina. Regional Environmental Change, 14(4), 1387-1394. https://doi.org/ 10.1007/s10113-013-0581-9

NRCS. (1986). Technical report 55, Urban hydrology for small watersheds. In U. D. of National Services Resources Conservation, Agriculture (Ed.), National Engineering Handbook. Washington, DC: United States Department of Agriculture.

O'Connell, C., Carlson, K., Cuadra, S., Feeley, K., Gerber, J., West, P., \& Polasky, S. (2018). Balancing tradeoffs: Reconciling multiple environmental goals when ecosystem services vary regionally. Environmental Research Letters, 13(6), https://doi.org/10.1088/1748-9326/aaafd8

Palomo, I., Willemen, L., Drakou, E., Burkhard, B., Crossman, N., Bellamy, C., ... Verweij, P. (2018). Practical solutions for bottlenecks in ecosystem services mapping. One Ecosystem, 3, e20713. https://doi. org/10.3897/oneeco.3.e20713

Parr, C. L., Lehmann, C. E. R., Bond, W. J., Hoffmann, W. A., \& Andersen, A. N. (2014). Tropical grassy biomes: Misunderstood, neglected, and under threat. Trends in Ecology \& Evolution, 29(4), 205-213. https:// doi.org/10.1016/j.tree.2014.02.004

Paruelo, J. M., Texeira, M., Staiano, L., Mastrángelo, M., Amdan, L., \& Gallego, F. (2016). An integrative index of ecosystem services provision based on remotely sensed data. Ecological Indicators, 71(August), 145-154. https://doi.org/10.1016/j.ecolind.2016.06.054

Pendrill, F., Persson, U. M., Godar, J., Kastner, T., Moran, D., Schmidt, S., $\&$ Wood, R. (2019). Agricultural and forestry trade drives large share of tropical deforestation emissions. Global Environmental Change, 56, 1-10. https://doi.org/10.1016/j.gloenvcha.2019.03.002

Piquer-Rodríguez, M., Baumann, M., Butsic, V., Gasparri, H. I., GavierPizarro, G., Volante, J. N., ... Kuemmerle, T. (2018). The potential impact of economic policies on future land-use conversions in Argentina. Land Use Policy, 79(June), 57-67. https://doi.org/10.1016/j.landu sepol.2018.07.039 
Piquer-Rodríguez, M., Butsic, V., Gärtner, P., Macchi, L., Baumann, M., Gavier Pizarro, G., ... Kuemmerle, T. (2018). Drivers of agricultural land-use change in the Argentine Pampas and Chaco regions. Applied Geography, 91, 111-122. https://doi.org/10.1016/j.apgeog.2018.01.004

Portalanza, D., Barral, M. P., Villa-Cox, G., Ferreira-Estafanous, S., Herrera, P., Durigon, A., \& Ferraz, S. (2019). Mapping ecosystem services in a rural landscape dominated by cacao crop: A case study for Los Rios province, Ecuador. Ecological Indicators, 107(July), 105593. https://doi.org/10.1016/j.ecolind.2019.105593

Potschin-Young, M., Haines-Young, R., Görg, C., Heink, U., Jax, K., \& Schleyer, C. (2018). Understanding the role of conceptual frameworks: Reading the ecosystem service cascade. Ecosystem Services, 29, 428-440. https://doi.org/10.1016/j.ecoser.2017.05.015

Potts, S., Imperatriz-Fonseca, V., Ngo, J., Biesmeijer, C., Breeze, T., Dicks, T., ... Cunningham, C. (2016). IPBES (2016): Summary for policymakers of the assessment report of the Intergovernmental SciencePolicy Platform on Biodiversity and Ecosystem Services on pollinators, pollination and food production (S. Potts, V. Imperatriz-Fonseca, \& T Ngo [Eds.]). Bonn, Germany: Secretariat of the Intergovernmental Science-Policy Platform on Biodiversity and Ecosystem Services, $552 \mathrm{pp}$.

Power, A. (2010). Ecosystem services and agriculture: Tradeoffs and synergies. Philosophical Transactions of the Royal Society B: Biological Sciences, 365(1554), 2959-2971.

Queen, J. P., Quinn, G. P., \& Keough, M. J. (2002). Experimental design and data analysis for biologists (1st ed.). Cambridge, UK: Cambridge University Press, $537 \mathrm{pp}$.

Queiroz, C., Meacham, M., Richter, K., Norström, A. V., Andersson, E., Norberg, J., \& Peterson, G. (2015). Mapping bundles of ecosystem services reveals distinct types of multifunctionality within a Swedish landscape. Ambio, 44(1), 89-101. https://doi.org/10.1007/s1328 0-014-0601-0

Quintas-Soriano, C., Castro, A. J., Castro, H., \& García-Llorente, M. (2016). Impacts of land use change on ecosystem services and implications for human well-being in Spanish drylands. Land Use Policy, 54, 534-548. https://doi.org/10.1016/j.landusepol.2016.03.011

Rau, A.-L., von Wehrden, H., \& Abson, D. J. (2018). Temporal dynamics of ecosystem services. Ecological Economics, 151, 122-130. https://doi. org/10.1016/j.ecolecon.2018.05.009

Raudsepp-Hearne, C., Peterson, G., \& Bennett, E. (2010). Ecosystem service bundles for analyzing tradeoffs in diverse landscapes. Proceedings of the National Academy of Sciences of the United States of America, 107(11), 5242-5247. https://doi.org/10.1073/pnas.09072 84107

Renard, D., Rhemtulla, J., \& Bennett, E. (2015). Historical dynamics in ecosystem service bundles. Proceedings of the National Academy of Sciences of the United States of America, 112(43), 13411-13416. https://doi.org/10.1073/pnas.1502565112

Renard, K., Foster, G., Weesies, G., \& Porter, J. (1991). RUSLE: Revised universal erosion equation. Journal of Soil and Water Conservation, 46, 30-33.

Rieb, J. T., Chaplin-Kramer, R., Daily, G. C., Armsworth, P. R., BöhningGaese, K., Bonn, A., ... Bennett, E. M. (2017). When, where, and how nature matters for ecosystem services: Challenges for the next generation of ecosystem service models. BioScience, 67(9), 820-833. https://doi.org/10.1093/biosci/bix075

Ripley, B. (1996). Pattern recognition and neural networks. Cambridge, UK: Cambridge University Press.

Riquier, J., Bramao, L., \& Cornet, S. (1970). A new system or soil appraisal in terms of actual and potential productivity. FAO Soil Resources, Development and Conservation Service (pp. 1-38). Rome, Italy: Land and Water Development Division, FAO.

Rogger, M., Agnoletti, M., Alaoui, A., Bathurst, J. C., Bodner, G., Borga, M., ... Blöschl, G. (2017). Land use change impacts on floods at the catchment scale: Challenges and opportunities for future research. Water
Resources Research, 53(7), 5209-5219. https://doi.org/10.1002/2017 WR020723

Rukundo, E., Liu, S., Dong, Y., Rutebuka, E., Asamoah, E. F., Xu, J., \& Wu, X. (2018). Spatio-temporal dynamics of critical ecosystem services in response to agricultural expansion in Rwanda, East Africa. Ecological Indicators, 89(December 2016), 696-705. https://doi.org/10.1016/j. ecolind.2018.02.032

Sacchi, L., Powell, P., Gasparri, N., \& Grau, R. (2017). Air quality loss in urban centers of the Argentinean Dry Chaco: Wind and dust control as two scientifically neglected ecosystem services. Ecosystem Services, 24, 234-240. https://doi.org/10.1016/j.ecoser. 2017.03.006

Schulp, C., Van Teeffelen, A., Tucker, G., \& Verburg, P. (2016). A quantitative assessment of policy options for no net loss of biodiversity and ecosystem services in the European Union. Land Use Policy, 57, 151-163. https://doi.org/10.1016/j.landusepol.2016.05.018

Semper-Pascual, A., Macchi, L., Sabatini, F. M., Decarre, J., Baumann, M., Blendinger, P. G., ... Kuemmerle, T. (2018). Mapping extinction debt highlights conservation opportunities for birds and mammals in the South American Chaco. Journal of Applied Ecology, 55(3), 1218-1229. https://doi.org/10.1111/1365-2664.13074

Seppelt, R., Dormann, C., Eppink, F., Lautenbach, S., \& Schmidt, S. (2011). A quantitative review of ecosystem service studies: Approches, shortcomings and the road ahead. Journal of Applied Ecology, 48, 630-636.

Solbrig, O. T. (1996). The diversity of the savanna ecosystem. In Biodiversity and savanna ecosystem processes. Ecological Studies (Vol. 121, pp. 1-27). Berlin, Heidelberg, Germany: Springer.

Song, X., Hansen, M., Stehman, S., Potapov, P., Tyukavina, A., Vermote, E., \& Townshend, J. (2018). Global land change from 1982 to 2016. Nature, 560(7720), 639-643.

Spangenberg, J. H., von Haaren, C., \& Settele, J. (2014). The ecosystem service cascade: Further developing the metaphor. Integrating societal processes to accommodate social processes and planning, and the case of bioenergy. Ecological Economics, 104, 22-32. https://doi. org/10.1016/j.ecolecon.2014.04.025

Strassburg, B. B. N., Brooks, T., Feltran-Barbieri, R., Iribarrem, A., Crouzeilles, R., Loyola, R., ... Balmford, A. (2017). Moment of truth for the Cerrado hotspot. Nature Ecology \& Evolution, 1(4), 99. https:// doi.org/10.1038/s41559-017-0099

Stürck, J., Verkerk, P. J., Mouchet, M. A., Schulp, C. J. E., Lavorel, S., Paracchini, M. L., \& Verburg, P. H. (2016). Bundles of ecosystem (dis)services and multifunctionality across European landscapes. Ecological Indicators, 73, 23-28. https://doi.org/10.1016/j.ecolind. 2016.09.026

Tilman, D., Balzer, C., Hill, J., \& Befort, B. (2011). Global food demand and the sustainable intensification of agriculture. Proceedings of the National Academy of Sciences of the United States of America, 108(50), 20260-20264. https://doi.org/10.1073/pnas.1116437108

Václavík, T., Lautenbach, S., Kuemmerle, T., \& Seppelt, R. (2013). Mapping global land system archetypes. Global Environmental Change, 23, 1637-1647. https://doi.org/10.1016/j.gloenvcha.2013. 09.004

Vallejos, M., Volante, J., Mosciaro, M., Vale, L., Bustamante, M., \& Paruelo, J. M. (2015). Transformation dynamics of the natural cover in the Dry Chaco ecoregion: A plot level geo-database from 1976 to 2012. Journal of Arid Environments, 123, 3-11. https://doi.org/10.1016/j. jaridenv.2014.11.009

Villarino, S., Studdert, G., Baldassini, P., Cendoya, M., Ciuffoli, L., Mastrángelo, M., \& Piñeiro, G. (2017). Deforestation impacts on soil organic carbon stocks in the Semiarid Chaco Region, Argentina. Science of the Total Environment, 575, 1056-1065. https://doi.org/ 10.1016/j.scitotenv.2016.09.175

Villarino, S., Studdert, G., \& Laterra, P. (2018). Greenhouse gas inventories: Deriving soil organic carbon change factors and assessing soil 
depth relevance in Argentinean Semiarid Chaco. Catena, 169, 164 174. https://doi.org/10.1016/j.catena.2018.05.041

Villarino, S., Studdert, G., \& Laterra, P. (2019). How does soil organic carbon mediate trade-offs between ecosystem services and agricultural production? Ecological Indicators, 103, 280-288. https://doi. org/10.1016/j.ecolind.2019.04.027

Volante, J. N., Alcaraz-Segura, D., Mosciaro, M. J., Viglizzo, E. F., \& Paruelo, J. M. (2012). Ecosystem functional changes associated with land clearing in NW Argentina. Agriculture, Ecosystems and Environment, 154, 12-22. https://doi.org/10.1016/j.agee.2011.08.012

Walesiak, M., \& Dudek, A. (2014). clusterSim: Searching for optimal clustering procedure for a data set. Retrieved from http://cran.r-project.org/ package $=$ clusterSim

Wehrens, R., \& Buydens, L. (2007). Self- and super-organizing maps in R: The kohonen package. Journal of Statistical Software, 21(5), 1-19.

Weyland, F., Barral, P., \& Laterra, P. (2017). Assessing the relationship between ecosystem functions and services: Importance of local ecological conditions. Ecological Indicators, 81(May), 201-213. https:// doi.org/10.1016/j.ecolind.2017.05.062

\section{SUPPORTING INFORMATION}

Additional supporting information may be found online in the Supporting Information section.

How to cite this article: Barral MP, Villarino S, Levers C, Baumann M, Kuemmerle T, Mastrangelo M. Widespread and major losses in multiple ecosystem services as a result of agricultural expansion in the Argentine Chaco. J Appl Ecol. 2020;00:1-14. https://doi.org/10.1111/1365-2664.13740 